\title{
DISIPLIN PEGAWAI BAGI APARAT DESA DI DESA CILELES, KECAMATAN JATINANGOR, KABUPATEN SUMEDANG
}

\author{
Amelia Cahyadini, Abi Ma'ruf Radjab, dan Muhamad Fadli Romadon \\ Fakultas Hukum, Universitas Padjadjaran \\ E-mail :amelia.cahyadini@unpad.ac.id
}

\begin{abstract}
ABSTRAK. Kewenangan yang dimiliki oleh pemerintah desa menuntut para pemerintah desa khususnya perangkat desa dapat melayani publik dengan optimal, namun hal tersebut belumlah dapat dilaksanakan karena berbagai faktor. Program ini berjudul Sosialisasi Bentuk-Bentuk Disiplin Pegawai Bagi Aparat Desa Di Desa Cileles, Kecamatan Jatinangor, Kabupaten Sumedang yang khusus ditujukan bagi para Aparat Desa, menurut bahasa yang digunakan undang-undang yaitu Perangkat Desa. Tujuan dari kegiatan ini yaitu memberikan sosialisasi tentang disiplin pegawai yang jika diterapkan di dalam perangkat desa akan membawa dampak positif bagi kinerjanya. Bentuk kegiatan ini yaitu wawancara untuk pemetaan masalah lalu setelahnya dilakukan sosialisasi dengan memberikan modul dan diskusi dengan perangkat desa yang dilakukan oleh tim peneliti dibantu dengan mahasiswa yang menjalankan program KKNM yang terintegrasi dengan riset dosen.
\end{abstract}

Kata kunci: Desa Cileles; Perangkat Desa; pelayanan publik; disiplin pegawai

ABSTRACT. The authority possessed by the village government requires that village governments, especially village officials, be able to serve the public optimally, but this has not been implemented due to various factors. The program is entitled Socialization of Forms of Employee Discipline for Village Officials in Cileles Village, Jatinangor Subdistrict, Sumedang District which is specifically intended for Village Officials, according to the language used by the law, namely Village Devices. The purpose of this activity is to provide information on employee discipline which if implemented in the village apparatus will have a positive impact on its performance. The form of this activity is an interview for mapping past problems after which socialization is carried out by providing modules and discussions with village officials conducted by the research team assisted by students who run the KKNM program which is integrated with lecturer research.

Key words: Cileles Village; Village Devices; public services; employee discipline

\section{PENDAHULUAN}

Kecamatan Jatinangor merupakan daerah dengan julukan kota pendidikan. Hal ini dikarenakan banyaknya institusi pendidikan tinggi di wilayah tersebut bahkan beberapa diantaranya merupakan perguruan tinggi terbaik di Indonesia. Melihat dari fakta ini tentu Jatinangor harus mampu mengikuti arus perubahan dan perkembangan karena selain memberi manfaat pada masyarakat Jatinangor, para mahasiswa dari perguruan tinggi-perguruan tinggi tersebut membawa banyak budaya kedalam Jatinangor yang mau tidak mau di terima oleh masyarakatnya. Kehidupan modern mulaimasuk dan menjadi acuan hidup bagi masyarakatnya. Namun hal tersebut belum mampu diterapkan pada kebiasaankebiasaan di lingkungan perkerjaan masyarakat tersebut. Termasuk kepada para Aparat Desa di wilayah Jatinangor.

Desa diatur melaluiUndang-Undang Nomor6Tahun 2014 Tentang Desa yang di dalamnya memiliki tujuan agar desa menjadi organisasi yang mandiri berdasarkan asas otonomi desa. Karenanya UU Desa memberikan wewenang yang cukup luas untuk mengatur desa bagi pemerintah desa. Aparat Desa atau yang menurut undangundang dikenal dengan Perangkat Desa merupakan salah satu unsur dalam pemerintahan desa. Posisi tersebut menjadikan jabatan perangkat desa sangatlah strategis untuk memberikan nilai kemanfaatan sesuai tugas dan fungsinya sebagai bagian pemerintahan negara Republik Indonesia dalam wilayah administrasi terkecil. Hal ini sejatinya bertentangan dengan asas kemandirian yang diamanatkan UU Desa. Nilai-Nilai kemandirian desa menjadi luntur ketika kebijakan administratif di berikan oleh instansi di atasnya kepada pemerintah desa. Sehingga mengakibatkan pemerintah desa menjadi sebuah organisasi birokrat yang setengah-setengah, yaitu di satu sisi haruslah mandiri sesuai dengan amanat peraturan perundang-undangan, namun di sisi lain haruslah tunduk dan mengkuti aturan-aturan yang dikeluarkan oleh instasi pemberi kebijakan. Contohnya yaitu dari Undang-Undang Nomor 25 Tahun 2009 Tentang Pelayanan Publik, pelayanan yang diselenggarakan oleh pemerintah desa yaitu pemberian dokumen-dokumen pemerintahan seperti perizinan, rekomendasi, surat keterangan, dan pendataan yang termasuk kedalam pelayanan administratif. Contoh lainnya adalah dari segi keuangan desa. UU Desa memberikan alokasi dana desa dari APBN, pajak dan retribusi daerah kabupaten/kota, alokasi dana desa yang merupakan bagian dari dana perimbangan yang diterima kabupaten/kota, serta bantuan keuangan dari APBD provinsi dan APBD kabupaten/kota yang semuanya itu menuntut adanya pengawasan dari pihak pemberi alokasi untuk pendapatan desa sesuai dengan UU Desa.

Kewenangan yang dimiliki oleh pemerintah desa menuntut para pemerintah desa khususnya perangkat 
desa dapat melayani publik dengan optimal, namun hal tersebut belumlah dapat dilaksanakan karena berbagai faktor seperti syarat menjadi kepala desa dan perangkat desa. Hal ini diperparah dengan kurangnya motivasi dari segi tunjangan pendapatan yang seharusnya dapat menjadi perhatian negara dalam hal kesejahteraan kepada perangkat desa yang belumlah layak. Selanjutnya faktor yang menjadi belum optimalnya pelayanan publik dari pemerintah desa adalah kurangnya program pembinaan desa dari pemerintah kabupaten/kota, pemerintah provinsi, maupun pemerintah pusat. Sehingga harus ada perbaikan dalam berbagai aspek.

Berbicara mengenai Aparat Desa atau yang menurut undang-undang dikenal dengan Perangkat Desa tidak dapat terlepas dari pembahasan mengenai Pemerintahan Desa. Berdasarkan Undang-Undang Nomor 6 Tahun 2014 Tentang Desa dalam Pasal 1 nomor 2 yaitu penyelenggaraan urusan pemerintahan dan kepentingan masyarakat setempat dalam sistem pemerintahan Negara Kesatuan Republik Indonesia. Sedangkan Pemerintah Desa menurut Pasal 1 nomor 3 undang-undang tersebut yaitu Kepala Desa atau yangdisebut dengan nama lain dibantu perangkat Desa sebagai unsur penyelenggara Pemerintahan Desa.

Seperti yang undang-undang amanatkan bahwa Pemerintah Desa merupakan Kepala Desa yang dibantu Perangkat Desa. Fungsi pembinaan yang seharusnya dapat menjadikan pemerintah desa dapat memahami aturan tentang tugas dan fungsinya juga belumlah berjalan baik. Hal ini berujung kepada kinerja yang belum optimal. Sehingga perlulah adanya pemberian sosialisasi mengenai disiplin pegawai yang dapat dijadikan rujukan dalam menjalankan fungsi pemerintahan desa. Program ini berjudul Sosialisasi Bentuk-Bentuk Disiplin Pegawai Bagi Aparat Desa Di Desa Cileles, Kecamatan Jatinangor, Kabupaten Sumedang. Tujuan dari kegiatan ini yaitu memberikan sosialisasi tentang pengaturan disiplin pegawai yang jika diterapkan di dalam perangkat desa akan membawa dampak positif bagi kinerjanya. Bentuk kegiatan ini yaitu wawancara untuk pemetaan masalah lalu setelahnya dilakukan sosialisasi dengan memberikan modul dan diskusi dengan perangkat desa yang dilakukan oleh tim peneliti dibantu dengan mahasiswa yang menjalankan program KKNM yang terintegrasi dengan riset dosen.

\section{METODE}

Metode yang digunakan adalah kualitatif. Penelitian ini menggunakan teknik pengumpulan data yaitu dengan studi kepustakaan tentang peraturan perundang-undangan mengenai pemerintahan desa dan hukum kepegawaian serta penelitian lapangan dengan wawancara para Perangkat Desa di Desa Cileles. Kemudian pemberian sosialisasi oleh dosen Hukum Administrasi Negara dalam bidang Hukum Kepegawaian Fakultas Hukum Universitas Padjadjaran serta dibantu tim peneliti serta mahasiswa KKNM Universitas Padjadjaran dengan bentuk pemberian modul kepada Perangkat Desa.

\section{HASIL DAN PEMBAHASAN}

Desa Cileles merupakan desa yang berbatasan langsung dengan wilayah kampus Universitas Padjadjaran dan termasuk salah satu desa binaan dari Universitas Padjadjaran. Desa Cileles memiliki luaswilayah 320 Ha dan jumlah penduduk sebanyak 6406 jiwa dengan kepadatan penduduk sebesar 387 orang/KMํ.Keadaan demografis Desa Cileles yaitu berbukit-bukit karena merupakan kaki gunung Manglayang dengan ketinggian desa 200 s/d 700 MDPL. Dari sekian banyak jumlah masyarakat yang tinggal di Desa Cileles, terbagi kedalam beberapa kelompok besar mata pencaharian yaitu buruh pabrik, bertani, beternak, wirausaha, dan tenaga pengajar. Dengan keadaan tersebut, Desa Cileles memiliki berbagai potensi yang masih dapat dioptimalkan untuk kemajuan desa dan masyarakatnya, yaitu diantaranya lahan yang subur yang cocok digunakan untuk bertani dan berkebun, tersedianya beberapa sumber air bersih dan struktur demografis yang cocok digunakan untuk beternak.

Struktur pemerintahan desa di Desa Cileles yaitu adanya Badan Permusywaratan Desa yang setara dengan kedudukan Kepala Desa, kemudian Kepala Desa Membawahi 4 Kepala Dusun serta Kepala Seksi Pemerintahan, Kepala Seksi Pelayanan, dan Kepala Seksi Kesejahteraan. Kemudian ada Sekretaris Desa selaku kepala administrasi desa membawahi 5 Kepala Urusan yaitu Kepala Urusan Umum, Kepala Urusan Perencanaan, Kepala Urusan Tata Usaha dan Umum, dan Kepala Urusan Keuangan dengan tabel sebagai berikut.
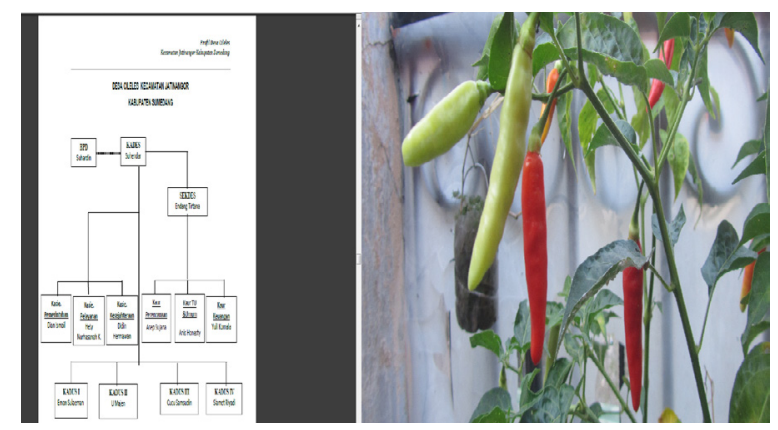

Dusun yang dibawahin oleh Desa Cileles berjumlah 4 dusun, yaitu Dusun 1 Narongtong yang memiliki 4 RW, Dusun 2 Cinenggang yang memiliki 2 RW, Dusun 3 Cileles yang memiliki 2 RW, Dusun 4 Cahyasari dan Lebakjati yang memiliki 2 RW.

Berdasarkan data yang telah diambil dalam pengumpulan data lapangan melalui proses wawancara kepada pemerintah desa yang berjumlah 12 orang dengan komposisi 1 orang kepala desa, satu orang sekretaris desa, serta 10 orang perangkat desa dengan pertanyaan mengenai pemahaman tentang kedudukan perangkat desa, pemahaman tentang disiplin pegawai, waktu yang dibutuhkan dalam pengurusan dokumen yang dibutuhkan masyarakat, serta beberapa terkait harapan para perangkat desa di Desa Cileles dalam hal pekerjaannya untuk dapat lebih baik. Kami memiliki beberapa pokok bahasan yang menjadi inti dari tulisan ini, yaitu sebagai berikut. 
I. Pemahaman Perangkat Desa tentang kedudukannya sebagai Perangkat Desa itu sendiri

Perangkat Desa sebagian besar sudah memahami bahwa mereka merupakan Perangkat Desa dalam artian mereka adalah bagian dari pemerintah desa yang mengatur mengenai hal yang bersifat administratif di desa. Mereka juga memahami mengenai tugas dan fungsinya sebagai Perangkat Desa dilihat dari penjabarannya tentang deskripsi pekerjaan di tiap-tiap jabatan.

Namun pada dasarnya mereka masih belum memahami secara keseluruhan tentang dasar aturan dan pedoman mereka dalam menjalankan pekerjaan dalam jabatannya sebagai Perangkat Desa. Sehingga masih terdapat banyaknya kekeliruan dalam menjalankan perannya dalam jabatan tersebut.

\section{Pemahaman Perangkat Desa tentang disiplin pegawai}

Disiplin pegawai merupakan hal yang menjadi pokok bahasan karena disini akan berpengaruh terkait kinerja yang dihasilkan oleh Perangkat Desa tersebut. Sebagian besar Perangkat Desa memahami tentang disiplin pegawai sebagai suatu bentuk aturan-aturan tentang tindakan yang harus dilakukan dan yang tidak boleh dilakukan khususnya pada jam kerja dan aturan dalam berpakaian.

Sejatinya disiplin pegawai merupakan suatu mekanisme yang harus dilakukan dalam menjalankan suatu jabatan sebagai pegawai karena dalam disiplin pegawai terdapat standar-standar yang harus terpenuhi dalam menjalankan suatu jabatan terlebih jabatan yang dimaksud adalah jabatan publik yang memiliki prosedur pengawasan dalam menilai kinerja.

Walaupun dari segi aturan, disiplin pegawai memanglah diperuntukkan untuk para Pegawai Negeri Sipil (PNS) bukan untuk perangkat desa yang memang secara kepegawaian hanya terikat dengan organisasi pemerintah desa saja, namun melihat adanya fungsi pelayanan publik yang dimiliki perangkat desa, maka tim peneliti menilai jika disiplin pegawai dapat dijadikan rujukan untuk menjalankan jabatan perangkat desa. Aturan disiplin pegawai mencakup tata cara pelayanan yang baik serta etika dalam menjalankan jabatan publik.

\section{Kinerja Perangkat Desa}

Merujuk pada Undang-Undang Desa Pasal 48 sampai Pasal 53, bentuk pertanggungjawaban Perangkat Desa sebatas pertanggungjawaban kerja atas tugas dan fungsinya dalam membantu Kepala Desa. Kemudian secara struktur yang bertanggungjawab secara langsung terhadap negara melalui Undang-Undang Desa ini adalah Kepala Desa itu sendiri.

Dalam Undang-Undang tersebut memang mengatur mengenai turunannya, seperti Peraturan Pemerintah, Peraturan Daerah Provinsi, maupun Peraturan Daerah Kabupaten/Kota mengenai Desa, namun pengaturan mengenai perangkat desa tetap dibebankan kepada Kepala Desa. Mengingat alasan diundangkannya Undang-Undang Desa seperti yang terdapat dalam poin menimbang, yaitu Desa memiliki hak asal usul dan hak tradisionaldalam mengatur dan mengurus kepentingan masyarakat setempat dan berperan mewujudkan cita-cita kemerdekaan berdasarkan Undang-Undang Dasar Negara Republik Indonesia Tahun 1945. Dalam perjalanan ketatanegaraan Republik Indonesia, Desa telah berkembang dalam berbagai bentuk sehingga perlu dilindungi dan diberdayakan agar menjadi kuat, maju, mandiri, dan demokratis sehingga dapat menciptakan landasan yang kuatdalam melaksanakan pemerintahan danpembangunan menuju masyarakat yang adil,makmur, dan sejahtera. Yang pada intinya Undang-Undang ini hanya mengakui dan mengatur Desa dengan tidak mengubah hak asal usul dan hak tradisional di dalamnya, namun dari sudut pandang hukum administrasi tetap diperlukan adanya asas profesionalitas di dalam pemerintahan desa, hal ini dikarenakan adanya kebijakan-kebijakan pusast maupun daerah yang memberikan desa wewenang administratif sehingga prosedur pengawasan dan pembinaan sesuai amanat UU Desa haruslah berjalan dengan baik apa lagi jika menyangkut hal-hal sensitif seperti masalah keuangan desa yang bersumber dari keuangan negara yang harus dapat dipertanggungjawabkan kepada publik.

Kinerja perangkat desa yang belum optimal disebabkan oleh beberapa faktor seperti syarat menjadi kepala desa dalam pasal 33 huruf c UU Desa yaitu berpendidikan paling rendah tamat sekolah mengah pertama atau sederajat, sedangkan perangkat desa pada pasal 50 ayat (1) huruf a yaitu berpendidikan paling rendah sekolah menengah umum atau sederajat yang dinilai belum mampu menunjang jabatannya sebagai pelayan publik yang di era modern ini dituntut mampu menggunakan teknologi maju dalam menujang tugasnya. Hal ini diperparah dengan kurangnya motivasi dari segi tunjangan pendapatan yang seharusnya dapat menjadi perhatian negara dalam hal kesejahteraan kepada perangkat desa yang belumlah layak. Kurangnya tunjangan pendapatan ditambah waktu kerja mereka pemerintahan desa yang tidak mengenal waktu, lebih tepatnya bisa saja 24 jam sehari dan 7 hari dalam seminggu. Karena perangkat desa haruslah menjadi penanggungjawab desa dalam keadaan apapun jadi kapanpun masyarakat membutuhkan mereka haruslah siap sedia. Selanjutnya faktor yang menjadi belum optimalnya pelayanan publik dari pemerintah desa adalah kurangnya program pembinaan desa dari pemerintah kabupaten/kota, pemerintah provinsi, maupun pemerintah pusat. Sehingga harus ada perbaikan dalam berbagai aspek.

Selanjutnya mengenai disiplin pegawai, dengan adanya sosialisasi disiplin pegawai kepada perangkat desa diharapkan mampu membuat para perangkat desa lebih profesional dalam menjalankan jabatannya dan mempermudah negara dalam mengatur mengenai disiplin perangkat desa mengingat semakin majunya zaman dan 
semakin banyak kebutuhan masyarakat khususnya dalam bidang pelayanan dan administrasi desa. Hal ini juga untuk menunjang program-program pemerintah yang mulai menggunakan teknologi maju dalam pelaksanaan pelayanan publik. Sehingga diharapkan para perangkat desa dapat menjadi para pelayan desa dengan tetap menjaga profesionalitas serta dapat turut menunjang kemajuan Negara Kesatuan Republik Indonesia dalam mencapai tujuan negara serta dapat mengikuti arus perubahan zaman.

Hasil dari penelitian ini adalah serangkaian sosialisasi tentang pentingnya disiplin pegawai dalam suatu organisasi profesional terkhusus lembaga peme-rintahan seperti Desa, sehingga mampu membuat para perangkat desa lebih profesional, disiplin, memiliki etos kerja, dan optimal dalam menjalankan jabatannya. Mengingat semakin majunya zaman dan semakin banyak kebutuhan masyarakat khususnya dalam bidang pelayanan dan administrasi desa. Hal ini juga untuk menunjang program-program pemerintah yang mulai menggunakan teknologi maju dalam pelaksanaan pelayanan publik. Sehingga diharapkan para perangkat desa dapat turut serta menunjang kemajuan Negara Kesatuan Republik Indonesia dalam mencapai tujuan negara serta dapat mengikuti arus perubahan zaman. Sosialisasi dilakukan dengan sistem pemberian modul yang isinya yaitu kumpulan peraturan tentang disiplin pegawai. Kemudian dilanjutkan dengan diskusi dari tim peneliti dengan para Perangkat Desa.

\section{SIMPULAN}

Desa Cileles merupakan salah satu desa binaan dari Universitas Padjadjaran. Dengan segenap potensi yang dimilikinya, desa ini diharapkan akan berkembang menjadi desa mandiri yang menjadi percontohan bagi desa lain khususnya dalam bidang pemerintahan desa. Sebagai sampel dalam pengambilan data tentang perangkat desa, permasalahan tentang sistem pemerintahan di dalamnya menjadi bahan yang cukup pantas dipertimbangkan oleh pemerintah pusat mengenai pembinaan dan pengawasan, serta penjaminan kesejahteraan bagi para perangkat desa di seluruh Indonesia.

Pemberian penyuluhan dan pendidikan harus dijalankan untuk memberikan pemahaman tentang tugas dan fungsi perangkat desa sesuai aturan yang ada. Disiplin pegawai merupakan suatu mekanisme yang harus dilakukan dalam menjalankan suatu jabatan sebagai pegawai karena dalam disiplin pegawai terdapat standar-standar yang harus terpenuhi dalam menjalankan suatu jabatan terlebih jabatan yang dimaksud adalah jabatan publik yang memiliki prosedur pengawasan dalam menilai kinerja. Kesejahteraan yang harus dijamin oleh pemerintah pusat dan daerah bagi pemerintahan di bawahnya. Sehingga pemerintahan desa akan menjadi pengusung kuatnya sistem pelayanan publik dari pemerintahan pusat di lingkup wilayah desa itu sendiri, sehingga membantu negara dalam mencapai tujuannya berdasarkan amanat Undang-Undang Dasar Negara Republik Indonesia Tahun 1945.

\section{DAFTAR PUSTAKA}

Irawan, Nata. 2017. Tata Kelola Pemerintahan Desa Era UU Desa. Jakarta: Yayasan Pustaka Obor Indonesia.

Kushandajani. 2018.Kewenangan Desa dan Penyelenggaraan Pemerintahan Desa dalam Perspektif UU No.6 Tahun 2014 tentang Desa. Semarang: Departemen Politik dan Pemerintahan FISIP Universitas Diponegoro.

Kusnadi, Agus. Perkembangan Politik Hukum Pemerintahan Desa Menurut Undang-Undang Nomor 32 Tahun 2004 Tentang Pemerintahan Daerah dan Undang-Undang Nomor 6 Tahun 2014 Tentang Desa. PADJADJARAN Jurnal Ilmu Hukum, Vol. 2 No. 3, Tahun 2015.

Lembong, Elazmanawati. Pemetaan Fisik dan Sosial Masyarakat di Desa Cileles Kecamatan Jatinangor Sumedang.Jurnal Pengabdian Kepada Masyarakat, Vol. 1, No. 5, Oktober 2017: 312 - 316.(http:// jurnal.unpad.ac.id/pkm/article/view/16417 yang diakses pada 11 Oktober 2018).

Tahir, M, Irwan. Model Efektifitas Organisasi Pemerintahan Desa. JurnalSosiohumaniora, Vol 19 No. 3, November 2017: 233 - 237. (http://jurnal. unpad.ac.id/sosiohumaniora/article/view/13070 yang diakses pada 8 November 2018).

Desa Cileles, Jatinangor, Sumedang (http://sumedang tandang.com/direktori/detail/desa-cileles.htm yang diakses pada 20 Agustus 2018).

Profil, Demografi, Tingkat Pendidikan Penduduk, Keadaan Sosial dan Budaya, Mata Pencaharian Penduduk, dan Struktur Organisasi Desa Cileles (https://desacilelesjtr.wordpress.com yang diakses pada 19 Agustus 2018). 